\title{
Богдана ШУлюк
}

кандидат економічних наук, доцент кафедри фінансів ім. С. І. Юрія, Тернопільський національний економічний університет, Тернопіль, Україна, BohdanaShulyuk@i.ua

ORCID ID: 0000-0001-8692-1983

\section{ФІНАНСОВI МЕТОДИ У СТРУКТУРІ ФІНАНСОВОГО МЕХАНІЗМУ ДЕРЖАВНО-ПРИВАТНОГО ПАРТНЕРСТВА: НАУКОВІ АСПЕКТИ ДОСАІДЖЕННЯ}

Вступ. Невід'ємною умовою функціонування фрінансового механізму державно-приватного партнерства є фрормування дієвих фрінансових методів. Разом із тим в економічній літературі відсутній єдиний підхід стосовно з'ясування сутності фрінансових методів та їх видів, що потребує активізації наукових зусиль, спрямованих на дослідження зазначених питань.

Mета - поглибити теоретико-концептуальний базис сутності фрінансових методів у структурі фрінансового механізму державно-приватного партнерства завдяки узагальненню та систематизації наукових підходів до їх розуміння у фраховій літературі.

Методи. У дослідженні використано методи діалектичного аналізу та синтезу, а також методи логічного узагальнення, порівняння і формалізації.

Результати. Висвітлено сутність фрінансових методів, як прояву дії фрінансового механізму державно-приватного партнерства. Під ними варто розуміти сукупність фрінансових процедур, що використовують у спільній діяльності держава і суб'єкти господарської діяльності задля виконання своїх фрункцій. Виокремлено їх види, зокрема: фрінансове планування, фрінансове забезпечення, фрінансове регулювання, фрінансовий облік, аналіз, оцінка результативності й ефрективності фрункціонування механізму, фрінансовий контроль.

Розкрито об'єктивну необхідність ефективного розроблення та результативного використання фрінансових методів у сфрері реалізації партнерських відносин держави $і$ бізнесу. Адже з їх допомогою створюються стратегічні й тактичні вектори діяльносmi, здійснюється мобілізація необхідних фрінансових ресурсів та раціональний їх розподіл, виконуються завдання учасників партнерства.

Зазначено, що актуальність зазначених питань зумовила значний інтерес $і$ увагу вчених до вивчення фрінансових методів. При цьому вказано на різнобічність висвітлення цього поняття у науковій літературі $i$, як наслідок, відсутність термінологічної бази його пізнання в сорері обраного дослідження.

Перспективи. Важливими є подальші наукові дослідження стосовно здійснення аналізу практичних аспектів використання фрінансових методів, що сприятиме з'ясуванню існуючих проблем і виокремленню напрямів їх вирішення.

() Богдана Степанівна Шулюк, 2019 
Ключові слова: фрінансовий механізм, державно-приватне партнерство, фрінансові методи.

Рис.: 2, бібл.: 24.

\section{Богдана ШУЛЮК}

кандидат экономических наук, доцент кафедры финансов им. С.И. Юрия, Тернопольский национальный экономический университет, Тернополь, Украина

\section{ФИНАНСОВЫЕ МЕТОДЫ В СТРУКТУРЕ ФИНАНСОВОГО МЕХАНИЗМА ГОСУДАРСТВЕННО-ЧАСТНОГО ПАРТНЕРСТВА: НАУЧНЫЕ АСПЕКТЫ ИССАЕДОВАНИЯ}

Введение. Неотъемлемым условием фрункционирования фринансового механизма государственно-частного партнерства является фрормирование действенных фринансовых методов. Вместе с тем в экономической литературе отсутствует единый подход к выяснению сущности фринансовых методов и их видов, что требует активизации научных усилий, направленных на исследование указанных вопросов.

Цель - углубить теоретико-концептуальный базис сущности фринансовых методов в структуре фринансового механизма государственно-частного партнерства с помощью обобщения и систематизации научных подходов к их пониманию в профессиональной литературе.

Методы. В исследовании использованы методы диалектического анализа и синтеза, а также методы логического обобщения, сравнения и формализации.

Результаты. Выяснена сущность финансовых методов, как проявление действия финансового механизма государственно-частного партнерства. Под ними следует понимать совокупность финансовых процедур, используемых в совместной деятельности государством и субъектами хозяйственной деятельности для выполнения своих функций. Выделены их виды, в частности: фринансовое планирование, фринансовое обеспечение, фринансовое регулирование, фринансовый учет, анализ, оценка результативности и эффрективности функционирования механизма, финансовый контроль.

Раскрыто объективную необходимость эффрективной разработки и результативного использования финансовых методов в сфрере реализации партнерских отношений государства и бизнеса. Ведь с их помощью создаются стратегические и тактические векторы деятельности, осуществляется мобилизация необходимых финансовых ресурсов и рациональное их распределение, выполняются задачи участников партнерства.

Указано, что актуальность перечисленных вопросов обусловила значительный интерес и внимание ученых к изучению финансовых методов. При этом отмечено разносторонность освещения этого понятия в научной литературе и, как следствие, отсутствие терминологической базы его познания в области избранного исследования.

Перспективы. Важны дальнейшие научные исследования по осуществлению анализа практических аспектов использования финансовых методов, которые будут способствовать выяснению существующих проблем и выделению направлений их решения.

Ключевые слова: финансовый механизм, государственно-частное партнерство, фринансовые методы. 


\section{Bohdana SHULIUK}

Ph.D. in Economics, Associate Prof. Department of Finance named after S.I. Yuriy, Ternopil National Economic University, Ternopil, Ukraine, BohdanaShulyuk@i.ua

ORCID ID: 0000-0001-8692-1983

\section{FINANCIAL METHODS IN THE STRUCTURE OF FINANCIAL MECHANISM OF STATE-PRIVATE PARTNERSHIP: SCIENTIFIC ASPECTS OF RESEARCH}

Introduction. An essential condition for the functioning of the financial mechanism of public-private partnership is the formation of effective financial methods. At the same time there is no single approach in the economic literature to finding out the essence of financial methods and their types, that needs activation of scientific efforts, noted questions directed on research.

Methods. We use methods of dialectical analysis and synthesis, as well as methods of logical generalization, comparison and formalization.

Results. The article outlines the essence of financial methods as a manifestation of the financial mechanism of public-private partnership. Under them it is necessary to understand the totality of financial procedures used in the joint activity of the state and economic entities for the performance of their functions. It was singled out their types, in particular: financial planning, financial support, financial regulation, financial accounting, analysis, evaluation of the effectiveness and efficiency of the mechanism, financial control.

The objective necessity of effective development and effective use of financial methods is exposed for the sphere of realization of partner relations between the state and business is revealed. After all, with the help of them, strategic and tactical vectors of activity are created, the mobilization of the necessary financial resources and rational distribution of them are carried out, the tasks of the partners of the partnership are fulfilled.

It is noted that the relevance of these issues caused considerable interest and attention of scientists to the study of financial methods. It noted the versatility of the coverage of this concept in the scientific literature, and as a consequence, the lack of a terminological basis of his knowledge in the field of selected research.

Conclusions. Financial methods occupy an important place in the structure of the financial mechanism of public-private partnership. After all, they allow to rationally plan the sources of formation and directions of the use of financial resources of public-private partnership, to effectively monitor the flow of financial flows, to monitor the status of payments and settlements with suppliers and customers, to evaluate the results of financial and economic activities of the partners. Consequently, the effectiveness, efficiency and effectiveness of the mechanism are ensured.

Keywords: financial mechanism, public-private partnership, financial methods.

JEL Classification: H43, H44, H54, H61, H72.

Постановка проблеми. Дієвість і результативність ффункціонування фрінансового механізму державно-приватного партнерства залежить від створення та застосування ефективних фрінансових методів. Використовуючи їх, учасники парт- нерства прагнуть забезпечити реалізацію намічених цілей, виконання стратегічних і тактичних завдань. Проте в економічній літературі відсутній єдиний підхід стосовно з'ясування сутності фрінансових методів та їх видів, що негативно відображається на 
конструктивності та розмаїтті напрямків удосконалення функціонування згаданого механізму як в теоретичній, так і практичній площині. Зважаючи на це, активізація наукових зусиль, спрямованих на дослідження зазначених питань, є актуальною.

Аналіз останніх досліджень і публікацій. Понятійний апарат стосовно змісту фінансового механізму, його складових, зокрема фрінансових методів, висвітлено в працях багатьох зарубіжних і вітчизняних вчених, зокрема: Л. Васечко [1], О. Василика [2], О. Колодізєва [3], Н. Мілякова [4], О. Міщук [5], В. Опаріна [6], В. Оспіщева [7], В. Родіонової [8], В. Федосова [9] та ін. Проте в економічній літературі відсутні концептуальні дослідження сутності фрінансових методів у структурі фрінансового механізму державноприватного партнерства. Зазначене обумовлює важливість теми дослідження.

Метою статті $€$ поглиблення теоретико-концептуального базису сутності фінансових методів у структурі фрінансового механізму державно-приватного партнерства завдяки узагальненню та систематизації наукових підходів до їх розуміння у фаховій літературі.

\section{Виклад основного матеріалу дослі-} дження. Важливими сегментами фінансового механізму державно-приватного партнерства (далі - ДПП) є фінансові методи. Вони відображають сукупність фрінансових процедур, які використовують у спільній діяльності держава і суб'єкти господарської діяльності задля виконання своїх функцій. До них належать: фрінансове планування, фрінансове забезпечення, фрінансове регулювання, фрінансовий облік, аналіз, оцінка результативності та ефективності механізму, фрінансовий контроль. Відтак варто деталізувати сутність кожного з них.

Фінансово-економічна невизначеність розвитку держави і суб'єктів господарювання зумовлює об'єктивну необхідність здійснення ефективного фінансового планування і прогнозування. Їх використання учасниками державно-приватного партнерства дасть змогу сформувати достатній обсяг фрінансових ресурсів, здійснювати виконання запланованих завдань і заходів з мінімальними витратами, а отже, домогтися успіху в довгостроковій перспективі. За допомогою фрінансового планування конкретизуються намічені прогнози, визначаються взаємопов'язані завдання і послідовність їх реалізації в досягненні обраної мети. Важливість і актуальність зазначених питань зумовили значний інтерес і увагу вчених до вивчення фрінансового планування. При цьому вказано на різнобічність висвітлення цього поняття в науковій літературі і, як наслідок, відсутність єдиної термінологічної бази його пізнання.

Узагальнивши авторські дефініції фрінансового планування, зазначимо, що вчені розглядають його як: процес прийняття управлінських рішень (так, О. Данілов розглядає фінансове планування на мікрорівні і розуміє під ним процес систематичної підготовки управлінських рішень, які прямо або опосередковано впливають на обсяги фінансових ресурсів, узгодження джерел їх формування та напрямків використання відповідно до виробничих і маркетингових планів, а також на величину показників підприємства в плановому періоді і які забезпечують виконання завдань найбільш раціональним шляхом [10, с. 200]); складання планів (зокрема, Б. Кузнєцов висвітлює це поняття як процес складання фінансового плану, яке тісно пов'язане з фінансовим прогнозуванням [11, с. 228]); фрінансову діяльність (Н. Міляков трактує дефініцію як вид фрінансової діяльності держави і господарюючих суб'єктів, орієнтованої на досягнення збалансованості між їх грошовими ресурсами і напрямками використання цих коштів [4, с. 34]). 
Таким чином, фрінансове планування як метод фінансового механізму ДПП - це процес складання стратегічних і оперативних планів учасниками партнерства стосовно обсягів та джерел фрормування фінансових ресурсів, напрямків їх використання відповідно до цілей спільної інвестиційної діяльності. Основою фрінансового планування $€$ фрінансове прогнозування, що дає змогу реалізувати окреслені завдання завдяки передбаченню впливу фрінансових ризиків і несприятливих економічних наслідків. Воно досліджує перспективні напрями розвитку спільної діяльності держави і бізнесу, тому має попередній характер, горизонти якого не об- межені плановим періодом і обов'язково мають враховувати ймовірні ризики.

Процес згаданого планування може мати різні цільові установки залежно від завдань, визначених державно-приватним партнерством. Загалом сутнісні складові фрінансового планування розкриваються через систему, котра охоплює об'єкт, предмет, принципи, мету, завдання та функції, авторське осмислення сутності та взаємозв'язку яких показано на рис. 1.

Формування цілісного розуміння про сутнісні складові фінансового планування дає можливість глибше і чіткіше визначити його значення в структурі фрінансового механізму державно-приватного партнер-

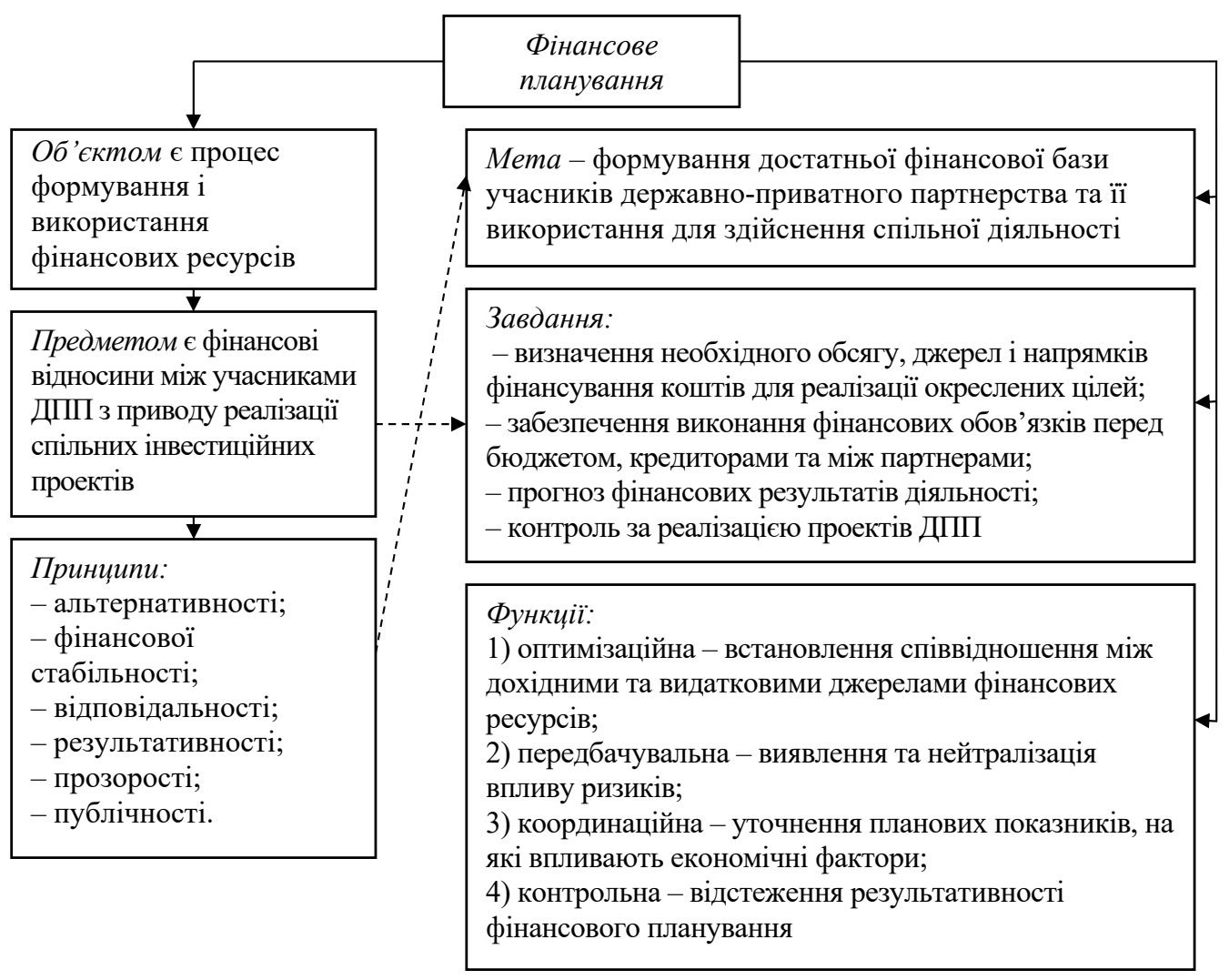

Рис. 1. Взаємозв'язок елементів фінансового планування у структурі фінансового *Побудовано автором. механізму державно-приватного партнерства* 
ства. Воно демонструє цілеспрямовану діяльність учасників партнерства в сфері прийняття обґрунтованих рішень щодо фінансового забезпечення господарської діяльності, розроблення, затвердження та реалізації економічно чи соціально значимих проектів, оптимізації передбачуваних витрат, визначення очікуваних результатів від спільної діяльності.

Вагомою складовою фрінансового механізму $є$ фрінансове забезпечення. В економічній літературі відсутній єдиний методологічний підхід до визначення цього поняття. Здебільшого науковці трактують його як: сукупність економічних відносин, які виникають у процесі фрормування та використання фрондів грошових коштів (С. Гладій [12], О. Колодізєв [3], І. Осмірко [13]); систему фінансових показників, що характеризують ефективність і результативність діяльності держави та суб'єктів господарської діяльності (І. Козій [14], О. Міщук [5]); покриття витрат завдяки акумулюванню фінансових ресурсів (В. Родионова, Ю. Вавілов, Л. Гончаренко [8]).

Фінансове забезпечення як метод фінансового механізму ДПП доцільно розглядати в триєдності ресурсного, управлінського та системного підходів. Відповідно до першого, поняття проявляється в необхідності акумулювання та розподілу фрінансових ресурсів з метою реалізації спільних проектів держави і бізнесу. Згідно з другим, результативність фінансового забезпечення залежить від ефективності управління вхідними та вихідними грошовими потоками. Третій підхід передбачає системне вирішення запланованих завдань, зокрема надання якісних соціальних послуг суспільству, фінансування стратегічно важливих об'єктів економічної інфраструктури, отримання фрінансової віддачі від спільної співпраці тощо.

Отже, фрінансове забезпечення в структурі фрінансового механізму ДПП можна ви- значити як процес формування, розподілу та використання фінансових ресурсів учасників партнерства з метою реалізації певних соціальних чи економічних цілей. Для глибшого розуміння сутності згаданої дефрініції, варто визначити її основні складові.

В. Опарін, В. Оспіщев, Г. Погріщук відносять до фрінансового забезпечення самофінансування, кредитування, зовнішнє фрінансування [6, с. $56 ; 7$, с. $59 ; 15$, с. 42], а В. Родіонова, В. Вавілов, Л. Гончаренко доповнюють зазначені складові державним фрінансуванням [8, с. 35-42]. Однак науковці не деталізують зазначені елементи, не враховують інноваційні форми фрінансування, а також гарантійне забезпечення діяльності держави та суб'єктів господарювання у випадку настання економічних ризиків.

Вважаємо, що фрінансове забезпечення здійснюється у наступних формах: фінансування, кредитування, залучення коштів, додаткове гарантійне забезпечення.

Розкриваючи сутність фрінансування, іноземні науковці часто ототожнюють його з результативним веденням будь-якої діяльності. Зокрема, французькі вчені І. Бернар і Ж.-К. Коллі вважають, що це поняття передбачає накопичення фінансових ресурсів, які необхідні для реалізації функцій держави, суб'єктів підприємницьких структур [16, с. 739-741]. Натомість Дж. Блек звужує його значення, обмежуючи державним фінансуванням [17, с. 285]. Відтак, фрінансування в структурі фрінансового механізму ДПП доцільно трактувати як забезпечення фрінансовими ресурсами спільних проектів і заходів учасників партнерства з метою досягнення запланованих економічних результатів чи соціальних ефектів. При цьому до його видів варто віднести самофрінансування (власні кошти підприємства); бюджетне фінансування на безповоротній основі; інноваційне фрінансування (факторинг, форфейтинг, лізинг, концесія), які да- 
ють змогу використовувати не тільки кошти держави і бізнесу, а й новітні джерела фрінансування.

Залучення коштів може здійснюватися шляхом кредитування, інвестування й отримання грантів. Перший вид реалізується у формі надання корпоративних облігаційних позик, державних і банківських кредитів. Найпоширенішою $є$ остання форма, що передбачає зовнішнє фрінансування проектів державно-приватного партнерства, коли держава і бізнес не мають достатніх фінансових можливостей для ведення спільної діяльності. Однак зазначені види кредитування практично не застосовують у вітчизняній практиці через високі ставки. Крім того, у світі активно використовують корпоративні облігаційні позики, які випускає і розміщує підприємницька структура задля використання отриманих коштів на фрінансування проектів державно-приватного партнерства.

Отримання інвестицій і грантів дає змогу органам державної і місцевої влади поліпшити бюджетну й соціально-економічну ефективність проекту. При цьому державі доцільно створювати сприятливі законодавчі, економічні та фрінансові умови для стимулювання зацікавленості інвесторів і спонсорів в розвитку державно-приватного партнерства.

Процес реалізації спільних проектів держави і бізнесу супроводжується макроекономічними (зміна валютного курсу, інфляція), правовими (скорочення або припинення фінансування проекту через зміну пріоритетів бюджетної політики, невідповідність законодавства в сфері оподаткування та інвестування, що може спричинити відмову приватного партнера виконувати умови угоди, відтак - економічні втрати), технічними (зміна умов навколишнього середовища, технічні проблеми) та фрінансовими ризиками (недоотримання очікуваних доходів від експлуатації об'єктів економічної інфраструктури, перевищення запланованих видатків на будівництво, модернізацію чи реконструкцію об'єкта). Оскільки участь у реалізації проектів державно-приватного партнерства обох партнерів супроводжується відповідними ризиками, особливої актуальності набувають методи їх мінімізації, зокрема державні та банківські гарантії, страхування.

Надання бюджетних (державних і місцевих) гарантій передбачає зобов'язання уряду погасити будь-яку нестачу коштів проектної компанії, пов'язаної з основними платежами та виплатою відсотків. Державні гарантії надаються виключно на умовах платності, строковості, майнового забезпечення та зустрічних гарантій, отриманих від інших економічних суб'єктів (ними можуть бути безвідзивні та безумовні гарантії фінансово-кредитних установ або інших підприємств). Обсяг державних гарантій, що надають приватному партнерові, визначається законом про державний бюджет на відповідний рік. Вони є короткостроковими, тому що їх обсяг не може бути прогнозованим на довгостроковий період. Відтак, основним призначенням місцевих гарантій $€$ підтримка інвестиційних програм, зокрема щодо розвитку комунальної інфраструктури регіону. Умови надання місцевих гарантій $є$ аналогічними до державних. Крім того, для виконання умов угоди приватним партнером можуть використовуватися банківські гарантії, а також страхування ризиків на випадок несприятливих погодних умов, коливань обмінного курсу, процентних ставок або цін на сировину, матеріали тощо.

Отож, фрінансове забезпечення розвитку державно-приватного партнерства передбачає здійснення заходів, спрямованих на мобілізацію необхідних фрінансових ресурсів, пошук та залучення зовнішніх інвесторів для реалізації спільних проектів з ме- 
тою підтримки стабільного функціонування економічної інфраструктури та підвищення якості надання послуг у різних сфрерах життєдіяльності суспільства.

Фінансове регулювання $€$ найважливішою складовою фінансового механізму ДПП, оскільки забезпечує раціональний і ефрективний розподіл ресурсів, створює сприятливі умови для реалізації спільних проектів держави і бізнесу. Згадане поняття, як і більшість економічних дефініцій, трактується неоднозначно. Науковці визначають його як систему відносин; метод впливу; сукупність методів, інструментів, важелів, засобів; управлінський процес.

3 позиції системного підходу фінансове регулювання відображає сукупність економічних чи розподільчих відносин, які реалізуються через фрінансовий механізм з метою забезпечення розвитку держави, суб'єктів господарювання та суспільства, зокрема через фрінансові інструменти [1, c. 106] чи фінансові методи [6, с. 61]. Проте автори не деталізують складники останніх та їхній взаємозв'язок.

О. Василик, В. Федосов та С. Юрій, розглядаючи фрінансове регулювання як метод, зазначають, що це - спосіб впливу на фінансову діяльність певного суб'єкта задля досягнення окресленої мети, виконання запланованих завдань [2, с. 103; 9, c. 98]. Таке трактування ототожнює фрінансове регулювання із такими складовими фінансового механізму, як фінансові методи. Відсутнє також розмежування й між фрінансовим регулюванням і фінансовим механізмом при визначенні вченими першого поняття як сукупності методів, інструментів, важелів, засобів впливу суб'єктів регулювання на підконтрольні об'єкти [18, с. 281; 19, с. 329].

Деякі автори визначають фрінансове регулювання як елемент системи управління соціально-економічними процесами, яке забезпечує підтримання внутрішньої стабільності, усунення відхилень у тих процесах, які визначають існування системи, її цілісність і побудову [20, с. 593]. Виникнення фінансового регулювання як управлінського процесу пов'язане, на нашу думку, з виконанням фінансами розподільчої і перерозподільчої функції (переміщенням ресурсів в часі і просторі).

Розподільчі процеси, які відбуваються в діяльності державно-приватного партнерства, протікають не завжди в потрібному для партнерів руслі, тому виникає необхідність фрінансового регулювання. Крім того, перерозподільчі процеси призводять до необхідності управління ризиками, які виникають у фрінансовій діяльності держави чи суб'єктів господарювання. За допомогою фінансового регулювання відбувається диверсифікація ризиків між партнерами завдяки використанню системи оподаткування, бюджетних трансфертів. Тому воно дає змогу забезпечити своєчасне та повне фінансування проектів ДПП, відтак досягти оперативних і стратегічних цілей партнерів.

Найбільш вживаними елементами фінансового механізму ДПП є фінансовий облік, аналіз, оцінка результативності й ефективності діяльності учасників партнерства. Перші два елементи - це дослідження фінансового забезпечення проектів ДПП, починаючи з проведення тендерів і завершуючи висновками стосовно досягнутих фінансових результатів.

Невід'ємним елементом фрінансового механізму ДПП є ефективність взаємодії учасників партнерства. 3 цього приводу А. Нікітаєва пише: "Ефективність управління досліджуваної взаємодії визначається якісними і кількісними характеристиками бізнес-сектору, держави, а також специфікою прямих і зворотних зв'язків між ними" [21, с. 27]. Водночас існує складність її оцінювання, що полягає в труднощах ви- 
окремлення одиниць вимірювання і розробки вимірювальних процедур, оскільки реалізовані заходи пов'язані з отриманням якісних результатів, які не завжди можна оцінити в кількісних показниках. У цьому випадку використовують методи розрахунку відносних і порівняльних показників, зокрема співвідношення між досягнутими результатами (ефектами) і витратами, пов'язаними із забезпеченням цих результатів; фактично досягнуті і необхідні результати (ефекти). Отже, досліджуваний елемент варто розглядати як перевищення ефекту від здійснення партнерських дій і заходів над витратами на їх розробку і реалізацію.

Вагоме значення у процесі визначення ефективності фінансового механізму ДПП має система критеріїв. Відповідно до світового досвіду, такі критерії поділяють на групи (рис. 2). Тому оцінити реальну ефективність функціонування фінансового ме- ханізму ДПП і реалізованих в його рамках проектів можливо лише в кожному окремому випадку такої співпраці.

Доцільно визначити схожість і відмінність між поняттями "ефективність" й "результативність". Якщо прийняті для оцінки есрективності критерії можуть бути кількісно виміряні (наприклад, за кількістю наданих послуг, обсягом перерахованих коштів, чисельністю реалізованих проектів в певній соціальній чи економічній сфері), то варто розглядати результативність як синонім есрективності. Якщо ж критерії не піддаються кількісному вимірюванню, то зазначені поняття не є синонімами.

Таким чином, зміст ефрективності і результативності фрінансового механізму державно-приватного партнерства полягає в досягненні мети співпраці партнерів (отриманні певного якісного результату діяльності або стану об'єкта фрінансування) при максимальній економії ресурсів.

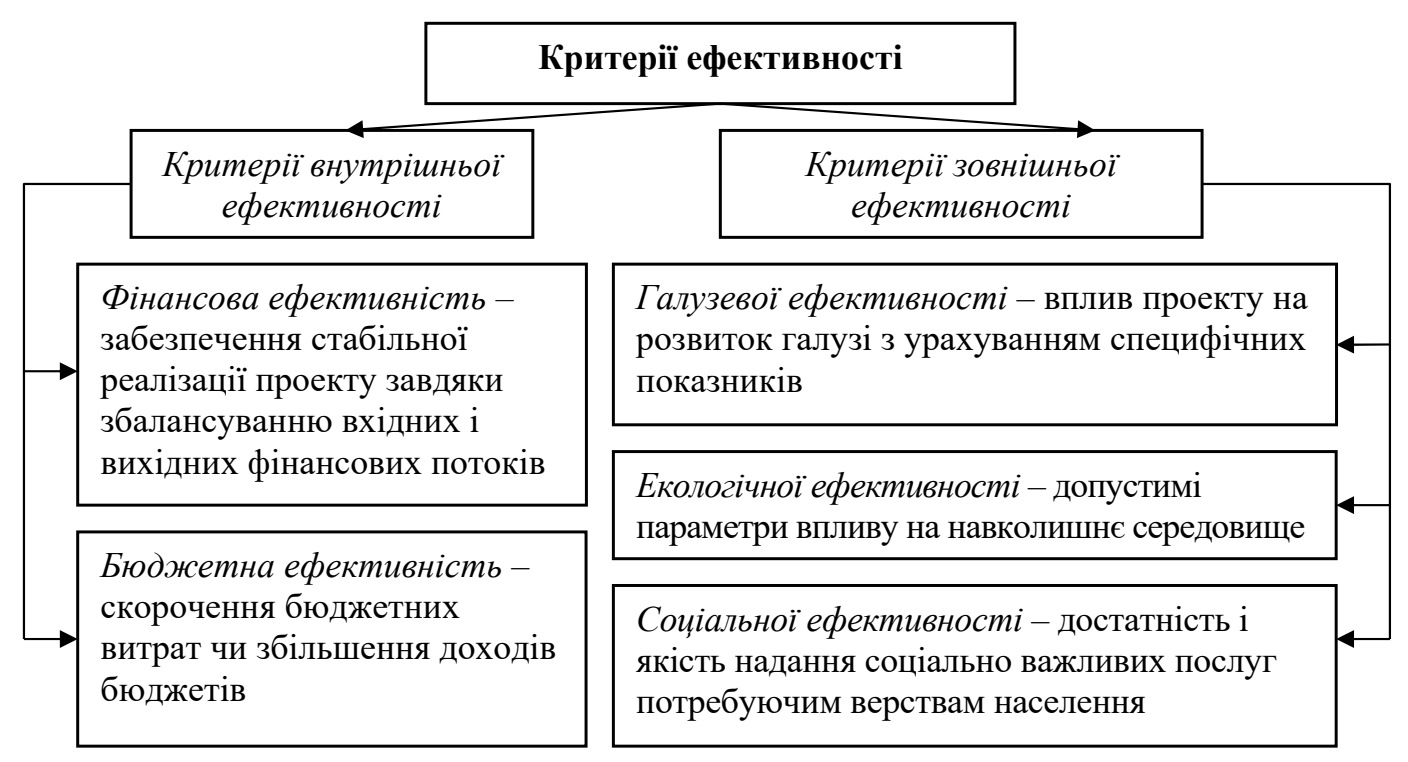

Рис. 2. Критерії ефективності функціонування фінансового механізму державно*Побудовано на основі [22; 23; 24]. приватного партнерства* 
Державним чи місцевим органам влади доцільно здійснювати постійний моніторинг і контроль за виконанням угод ДПП з метою координації взаємодії учасників партнерства, підвищення результативності й ефективності реалізації проектів. Такі елементи фінансового механізму ДПП характеризуються більшою тривалістю і складністю, забезпечуючи: дотримання сторонами угоди ДПП своїх зобов'язань, зокрема якісне надання послуг в певній сфрері інфраструктури, своєчасне здійснення платежів сторонами угоди; управління ризиками обох сторін; реагування на виклики зовнішнього середовища в контексті виникнення загроз і нових можливостей для проекту.

Висновки. Фінансові методи посідають важливе місце в структурі фрінансового механізму державно-приватного партнерства. Адже вони дають змогу раціонально планувати джерела фрормування та напрямки використання фінансових ресурсів державно-приватного партнерства, здійснювати ефективний контроль за рухом фінансових потоків, відстежувати стан здійснених платежів і розрахунків із постачальниками і замовниками, оцінювати результати фінансово-господарської діяльності учасників партнерства. Відтак, забезпечують дієвість, ефективність і результативність функціонування згаданого механізму. Водночас актуальними $€$ подальші наукові дослідження стосовно здійснення аналізу практичних аспектів використання фінансових методів, що сприятиме з'ясуванню існуючих проблем і виокремленню напрямів їх вирішення.

\section{Список використаних джерел}

1. Васечко Л. І. Співвідношення понять "фpiнансовий механізм", "механізм фрінансування", "фонансове забезпечення", "фрінансове регулювання". Вісник Львівського університету. Серія: Економіка. 2009. № 41. С. 103-107.
2. Василик О. Д. Теорія фрінансів. Київ: НІОС, 2000. $416 \mathrm{c}$.

3. Колодізєв О. М. Методологічні засади фрінансового забезпечення управління інноваційним розвитком економіки : монографрія. Харків : IHЖEK, 2009. 239 c.

4. Миляков Н. В. Финансы : учебник. 2-е изд. Москва: ИНФРА_М, 2004. 543 C.

5. Мімук О. В. Фінансове забезпечення економічного зростання: теоретичний аспект. Науковий вісник: Фінанси, банки, інвестиції. 2011. № 2. C. 9-12.

6. Опарін В. М. Фінанси (Загальна теорія) : навч. посібник. 2-ге вид., доп. і перероб. Київ : KHEY, 2002. $240 \mathrm{c}$.

7. Фінанси : навч. посібник / О. П. Близнюк, Л. І. Лачкова, В. І. Оспіщев та ін. ; за ред. І. В. Оспіщева. Київ : Знання, 2006. 415 c.

8. Финансы / В. М. Родионова, В. Я. Вавилов, Л. И. Гончаренко и др.; под ред. В. М. Родионовой. Москва: Финансы и статистика, 1993. 432 c.

9. Фінанси : підручник. 2-ге вид., доп. і переробл. / за ред. С. І. Юрія, В. М. Федосова. Київ : Знання, 2012. $687 \mathrm{c.}$

10. Данілов О. Д., Паєнтко Т. В. Фінанси підприємств у запитаннях і відповідях : навч. посіб. Київ : Центр учбової літератури, 2011. 256 с.

11. Кузнецов Б. Т. Финансовый менеджмент : учеб. пособ. для студ. вузов. Москва : ЮНИТИ-ДАНА, 2005. 415 С.

12. Гладій С. Фінансовий механізм інвестування інноваційного розвитку: теоретико-методологічний підхід до управління. Наука молода. 2005. № 3. С. 109-115.

13. Осмірко І. В. Система фрінансового забезпечення інноваційного розвитку: поняття, структура та принципи функціонування. Бізнес Інформ. 2012. № 7. С. 47-49.

14. Козій I. С. Місце і значення фрінансового забезпечення в структурі фрінансового механізму. Науковий вісник НЛтУ України. 2008. Вип. 18.9. С. 223-229.

15. Погріщук Г. Б. Фінансове забезпечення охорони навколишнього природного середови- 
ща : авторефр. дис. ... канд. екон. наук : 08.04.01. Тернопіль, 2005. 20 с.

16. Бернар И., Колли Ж.-К. Толковый экономический и финансовый словарь: французская, русская, английская, испанская терминология : в 2-х т. T. 1. Пер. с фрр. Москва : Междунар. отношения, 1997. 784 с.

17. Блэк Дж. Экономика. Толковый словарь: англо-русский. Москва : ИНФРА-М, 2000. 840 с.

18. Мацьків В. В. Теоретичні основи фрінансового регулювання зовнішньоекономічної діяльності суб'єктів господарювання. Актуальні проблеми розвитку економіки регіону. 2012. Вип. 8 (1). С. 279-290.

19. Алескерова Ю. В. Державне фрінансове регулювання аграрного сектору економіки. Східна Європа: економіка, бізнес та управління. 2016. Вип. 4. С. 328-331.

20. Антикризисное управление : учебник. 2-е изд., доп. и перераб. / под ред. Э. М. Короткова. Москва : ИНФРА-М., 2010. 620 с.

21. Никитаева А. Ю. Управление взаимодействием государства и бизнеса в экономической системе региона: методология, теория, механизмы : авторефр. дис. ... д-ра экон. наук : 05.13.10 / Южный федеральный университет. Ростов-на-Дону, 2008. 50 c. URL : https://dlib.rsl.ru/viewer/01003172075\#?page=27.

22. Макаров И. Н., Колесников В. В. Аудит эффрективности и производство опекаемых благ: взгляд с позиции экономической социодинамики. Российское предпринимательство. 2010. № 6. C. 51-55.

23. Макаров И. Н., Манасян С. М. Теоретико-методологические основы анализа эффрективности проектов ГЧП в добывающей промышленности и ТЭК страны. Российское предпринимательство. 2014. № 1. С. 148-163.

24. Макаров И. Н., Колесников В. В., Гудович Г. К., Рязанцева Е. А. Инвестиционный контроль и аудит промышленных проектов на базе государственно-частного партнерства. Российское предпринимательство. 2018. Т. 19. № 5. C. 1533-1542.

\section{References}

1. Vasechko, L. I. (2009). Spivvidnoshennia poniat "finansovyi mekhanizm", "mekhanizm finansuvannia", "finansove zabezpechennia", "finansove rehuliuvannia" [Correlation of the concepts of "financial mechanism", "financing mechanism", "financial security", "financial regulation"]. Visnyk Lvivskoho universytetu. Seriia: Ekonomika - Bulletin of Lviv University. Series: Economics, 41, 103107 [in Ukrainian].

2. Vasylyk, O. D. (2000). Teoriia finansiv [The theory of finance]. Kyiv: NIOS [in Ukrainian].

3. Kolodiziev, O. M. (2009). Metodolohichni zasady finansovoho zabezpechennia upravlinnia innovatsiinym rozvytkom ekonomiky [Methodological fundamentals of financial management of innovation development of the economy]. Kharkiv: INZHEK [in Ukrainian].

4. Milyakov, N. V. (2004). Finansyi [Finance]. (2nd ed., rev.). Moscow: INFRA-M [in Russian].

5. Mishchuk, O. V. (2011). Finansove zabezpechennia ekonomichnoho zrostannia: teoretychnyi aspect [Financial support for economic growth: the theoretical aspect]. Naukovyi visnyk: finansy, banky, investytsii - Scientific Bulletin: Finance, Banks, Investments, 2, 9-12 [in Ukrainian].

6. Oparin, V. M. (2002). Finansy (Zahalna teoriia) [Finance (General theory)]. (2nd ed., rev.). Kyiv: KNEU [in Ukrainian].

7. Blyzniuk, O. P., Lachkova, L. I., Ospishchev, V. I. (Ed.). (2006). Finansy [Finance]. Kyiv: Znannia [in Ukrainian].

8. Rodionova, V. M. (Ed.), Vavilov, V. Y., Goncharenko, L. I. (1993). Finansyi [Finance]. Moscow: Finansyi i statistika [in Russian].

9. Yurii, S. I., Fedosov, V. M. (2012). Finansy [Finance]. (2nd ed., rev.). Kyiv: Znannia [in Ukrainian].

10. Danilov, O. D., Paientko, T. V. (2011). Finansy pidpryiemstv u zapytanniakh $i$ vidpovidiakh [Finance of enterprises in questions and answers]. Kyiv: Tsentr uchbovoi literatury [in Ukrainian].

11. Kuznetsov, B. T. (2005). Finansovyiy menedzhment [Financial management]. Moscow: UNITI-DANA [in Russian]. 


\section{ДЕРЖАВНI ФIНАНСИ}

12. Hladii, S. (2005). Finansovyi mekhanizm investuvannia innovatsiinoho rozvytku: teoretykometodolohichnyi pidkhid do upravlinnia [Financial mechanism of investment of innovative development: theoretical and methodological approach to management]. Nauka moloda - Young Science, 3, 109-115 [in Ukrainian].

13. Osmirko, I. V. (2012). Systema finansovoho zabezpechennia innovatsiinoho rozvytku: poniattia, struktura ta pryntsypy funktsionuvannia [System of financial support of innovative development: concept, structure and principles of functioning]. Biznes Inform - Business Inform, 7, 47-49 [in Ukrainian].

14. Kozii, I. S. (2008). Mistse i znachennia finansovoho zabezpechennia $v$ strukturi finansovoho mekhanizmu [The place and value of financial security in the structure of the financial mechanism]. Naukovyi visnyk NLTU Ukrainy - Scientific Bulletin of NLTU of Ukraine, 18.9, 223-229 [in Ukrainian].

15. Pohrishchuk, H. B. (2005). Finansove zabezpechennia okhorony navkolyshnoho pryrodnoho seredovyshcha [Financial support for the protection of the environment]. (Thesis 08.04.01). Ternopil [in Ukrainian].

16. Bernar, I., Kolli, Zh.-K. (1997). Tolkovyiy ekonomicheskiy i finansovyiy slovar: frantsuzskaya, russkaya, angliyskaya, ispanskaya terminologiya [Explanatory economic and financial dictionary: French, Russian, English, Spanish terminology]. Moscow: Mezhdunarodnyie otnosheniya [in Russian].

17. Blek, Dzh. (2000). Ekonomika. Tolkovyiy slovar: anglo-russkiy [Economy. Explanatory dictionary: English-Russian]. Moscow: INFRA-M [in Russian].

18. Matskiv, V. V. (2012). Teoretychni osnovy finansovoho rehuliuvannia zovnishnoekonomichnoi diialnosti subiektiv hospodariuvannia [Theoretical bases of financial regulation of foreign economic activity of business entities]. Aktualni problemy rozvytku ekonomiky rehionu - Actual problems of the region's economy development, 8 (1), 279-290 [in Ukrainian].

19. Aleskerova, Y. V. (2016). [Derzhavne finansove rehuliuvannia ahrarnoho sektory ekonomiky [State financial regulation of the agrarian sector of the economy]. Skhidna Yevropa: ekonomika, biznes ta upravlinnia - Eastern Europe: Economics, Business and Management, 4, 328331 [in Ukrainian].

20. Korotkov, E. M. (Ed.). (2010). Antikrizisnoe upravlenie [Anti-crisis management]. (2nd ed., rev.). Moscow: INFRA-M [in Russian].

21. Nikitaeva, A. Yu. (2008). Upravlenie vzaimodeystviem gosudarstva i biznesa v ekonomicheskoy sisteme regiona: metodologiya, teoriya, mehanizmyi [Management of state and business interaction in the regional economic system: methodology, theory, mechanisms]. (Thesis 05.13.10). Rostow-na-Dony. Available at: https://dlib.rsl.rul viewer/01003172075\#?page=27.

22. Makarov, I. N., Kolesnikov, V. V. (2010). Audit effektivnosti i proizvodstvo opekaemyih blag: vzglyad s pozitsii ekonomicheskoy sotsiodinamiki [Performance audit and production of protected goods: a view from the standpoint of economic sociodynamics]. Rossiyskoe predprinimatelstvo Russian business, 6, 51-55 [in Russian].

23. Makarov, I. N., Manasyan, S. M. (2014). Teoretiko-metodologicheskie osnovyi analiza effektivnosti proektov GChP $v$ dobyivayuschey promyishlennosti $i$ TEK stranyi [Theoretical and methodological foundations of the analysis of the effectiveness of PPP projects in the extractive industry and fuel and energy sector of the country]. Rossiyskoe predprinimatelstvo - Russian business, 1, 148-163 [in Russian].

24. Makarov, I. N., Kolesnikov, V. V., Gudovich, G. K., Ryazantseva, E. A. (2018). Investitsionnyiy kontrol $i$ audit promyishlennyih proektov na baze gosudarstvenno-chastnogo partnerstva [Investment control and audit of industrial projects based on public-private partnership]. Rossiyskoe predprinimatelstvo - Russian business, 5, 15331542 (Vol. 19) [in Russian].

Стаття надійшла до редакції 12.03.2019. 